\title{
Texture and composition of the Rosa Marina beach sands (Adriatic coast, southern Italy): a sedimentological/ecological approach
}

\author{
Massimo Moretti ${ }^{1, *}$, Marcello Tropeano ${ }^{2}$, A.J. (Tom) van Loon ${ }^{3}$, \\ Pasquale Acquafredda ${ }^{4}$, Rossella Baldacconi ${ }^{5}$, Vincenzo Festa ${ }^{6}$, \\ Stefania Lisco ${ }^{7}$, Giuseppe Mastronuzzi ${ }^{8}$, Vincenzo Moretti ${ }^{9}$, Rosa Scotti ${ }^{10}$ \\ ${ }^{1}$ Dipartimento di Scienze della Terra e Geoambientali, Università degli Studi di Bari, Campus Universitario, \\ via E. Orabona 4, I-70100, Bari, Italy; e-mail: massimo.moretti@uniba.it \\ ${ }^{2}$ Dipartimento di Scienze della Terra e Geoambientali, Università degli Studi di Bari, Campus Universitario, \\ via E. Orabona 4, I-70100, Bari, Italy; e-mail: marcello.tropeano@uniba.it \\ ${ }^{3}$ Geocom, Valle del Portet 17, 03726 Benitachell, Spain; e-mail: Geocom.VanLoon@gmail.com \\ ${ }^{4}$ Dipartimento di Scienze della Terra e Geoambientali, Università degli Studi di Bari, Campus Universitario, \\ via E. Orabona 4, I-70100, Bari, Italy; e-mail: pasquale.acquafredda@uniba.it \\ ${ }^{5}$ Freelancer, via Gastone Mezzetti 21, Taranto, Italy; e-mail: rossella_baldacconi@msn.com \\ ${ }^{6}$ Dipartimento di Scienze della Terra e Geoambientali, Università degli Studi di Bari, Campus Universitario, \\ via E. Orabona 4, I-70100, Bari, Italy; e-mail: vincenzo.festa@uniba.it \\ ${ }^{7}$ Dipartimento di Scienze della Terra e Geoambientali, Università degli Studi di Bari, Campus Universitario, \\ via E. Orabona 4, I-70100, Bari, Italy; e-mail: ste.lisco@hotmail.it \\ ${ }^{8}$ Dipartimento di Scienze della Terra e Geoambientali, Università degli Studi di Bari, Campus Universitario, \\ via E. Orabona 4, I-70100, Bari, Italy; e-mail: gimastronuzzi@libero.it \\ ${ }^{9}$ Regione Puglia - Servizio Ecologia - Ufficio Programmazione, politiche energetiche, VIA e VAS, via delle Magnolie, \\ 6/8 - 70026 Modugno, Bari, Italy; e-mail: moretti_enzo@yahoo.it, v.moretti@regione.puglia.it \\ ${ }^{10}$ Freelancer, via Leonida 31, Taranto, Italy; e-mail: scotti.rosa1980@gmail.com \\ * corresponding author
}

\begin{abstract}
Beach sands from the Rosa Marina locality (Adriatic coast, southern Italy) were analysed mainly microscopically in order to trace the source areas of their lithoclastic and bioclastic components. The main cropping out sedimentary units were also studied with the objective to identify the potential source areas of lithoclasts. This allowed to establish how the various rock units contribute to the formation of beach sands. The analysis of the bioclastic components allows to estimate the actual role of organisms regarding the supply of this material to the beach. Identification of taxa that are present in the beach sands as shell fragments or other remains was carried out at the genus or family level. Ecological investigation of the same beach and the recognition of sub-environments (mainly distinguished on the basis of the nature of the substrate and of the water depth) was the key topic that allowed to establish the actual source areas of bioclasts in the Rosa Marina beach sands. The sedimentological analysis (including a physical study of the beach and the calculation of some statistical parameters concerning the grain-size curves) shows that the Rosa Marina beach is nowadays subject to erosion.
\end{abstract}

Keywords: source-area reconstruction, grain-size analysis, mineralogical composition, image analysis, coastal erosion 


\section{Introduction}

Beaches attract much interest from earth scientists nowadays (Schwartz, 2005), in particular from sedimentologists (Greenwood \& Davies, 1984) and geomorphologists (Bird, 2008). Understanding the mechanisms which regulate the evolution of the beaches is not a simple scientific exercise, but understanding of these mechanisms may have an important economic and social impact; numerous scientific articles and books therefore focus on a variety of geological features concerning beaches. These fearures include shoreline dynamics (Ingle, 1966; Fredsøe \& Deigaard, 1994; Anthony, 2009), coastal erosion (Charlier \& De Meyer, 1998; Uda, 2010; Van Rijn, 2011), management and monitoring of coastal areas (NRC, 1989; Kay \& Alder, 2002) and beach nourishment (Finkl, 1981; NRC, 1989; Nordstrom, 2005).

Beaches form an environment where ecological and biological factors tend to play a pivotal role with regard to the physical evolution of the system; nonetheless only few studies describing the interactions between the biological processes and the sedimentary dynamics in coastal areas have been published so far (NRC, 1994a,b).

In shallow-marine environments, sediment may result from the redistribution (due to waves, tides and currents) of the material supplied by rivers and/or eroded from rocks in the coastal area (both types form terrigenous clastic material) or from the production of clastic particles in the marine environment by biotic and/or abiotic processes (autochthonous clastic material). Sediments generated by biotic processes are most commonly carbonates; beach sediments therefore tend to contain a variable percentage of carbonates, derived from bioclasts (i.e., shells or fragments of marine organisms).

The study of the complex interactions between physical and biological processes provides key information for monitoring, protection and restoration of coastal areas. For example, beach nourishment by supply of sand that replaces eroded sediment (Chiocci \& La Monica, 1999; Van der Salm \& Unal, 2003; Nicoletti et al., 2006; APAT-ICRAM, 2007; Anfuso et al., 2011) needs: - a physical characterisation of the site of interest; - a chemical characterisation of the sediments to be supplied (with particular attention for their organic and inorganic pollution); - detailed biological and ecological analyses on the benthic populations, the presence of seagrasses, nursery areas, as well as attention to the impact of beach nourishment on the biotope (Colosio et al., 2007). Furthermore, the suitability of sand (coastal or relict) for beach nourishment ultimately depends on its 'compatibility' with the sands of the coast to be replenished; the definition of 'compatibility' requires a quantitative evaluation of the textural, petrographical and mineralogical parameters of the main (both lithoclastic and bioclastic) sediment constituents (colour, sieve size intervals of $1 / 2 \varphi$, main mineralogical characteristics, etc.).

The present contribution describes a multidisciplinary approach in the study of a beach. It focuses on the interaction between the organisms living in the depths of the coastal areas and the physical processes connected to sedimentation. Both aspects are closely related, especially with regard to sediment production: the relationship between lithoclastic and bioclastic sediment in the Rosa Marina coastal area, along the Adriatic sector of the Apulian region is shown. A methodology for beach-sediment analysis is presented, aimed at both textural/petrographical characterisation of the sands and at the definition of the bioclast content as related to benthic populations and their relationships with the sandy or rocky substrate.

\section{Geological setting}

The Rosa Marina beach $\left(\mathrm{N} 40^{\circ} 50^{\prime}, \mathrm{E} 17^{\circ} 50^{\prime}\right)$ is located north of Brindisi, along the southeastern Adriatic coast of Italy (Fig. 1). It is characterised by a great touristic and economic pressure, housing two private tourist-residential consortia (for a total of over 1,000 villas), a hotel-resort, swimming pools, etc. It is part of the Regional Natural Park of the Coastal Dunes between 'Torre Canne' and 'Torre San Leonardo' (established by Regional Law 31, dated 26-10-2006). This coastal area includes small catchment areas through which ephemeral streams run ('Pilone Vallone' and 'Rosa Marina Lama': Fig. 1) that are capable to carry only moderate amounts of sediments to the sea, usually during intense weather events. This contributes to the building of a coastal wedge in a microtidal setting where the littoral dynamics are wave-dominated. The wave conditions, deduced from the 1968-2008 data of a wave buoy at Monopoli (N4058'30.0”', E17²2'36.1”, less than $25 \mathrm{~km}$ from the beach under study) indicate that the prevailing direction of sea storms is from the north-west. The sediment transport by traction along the coast should, therefore, mainly occur in a NW-SE direction (Mastronuzzi et al., 2002).

This Apulian coastal sector often shows a linear trend, with low-elevation, active sandy coastal dunes and well-developed backshore marsh areas (south of Torre Canne). From Pilone to the southern Monticelli (an area including Rosa Marina), 


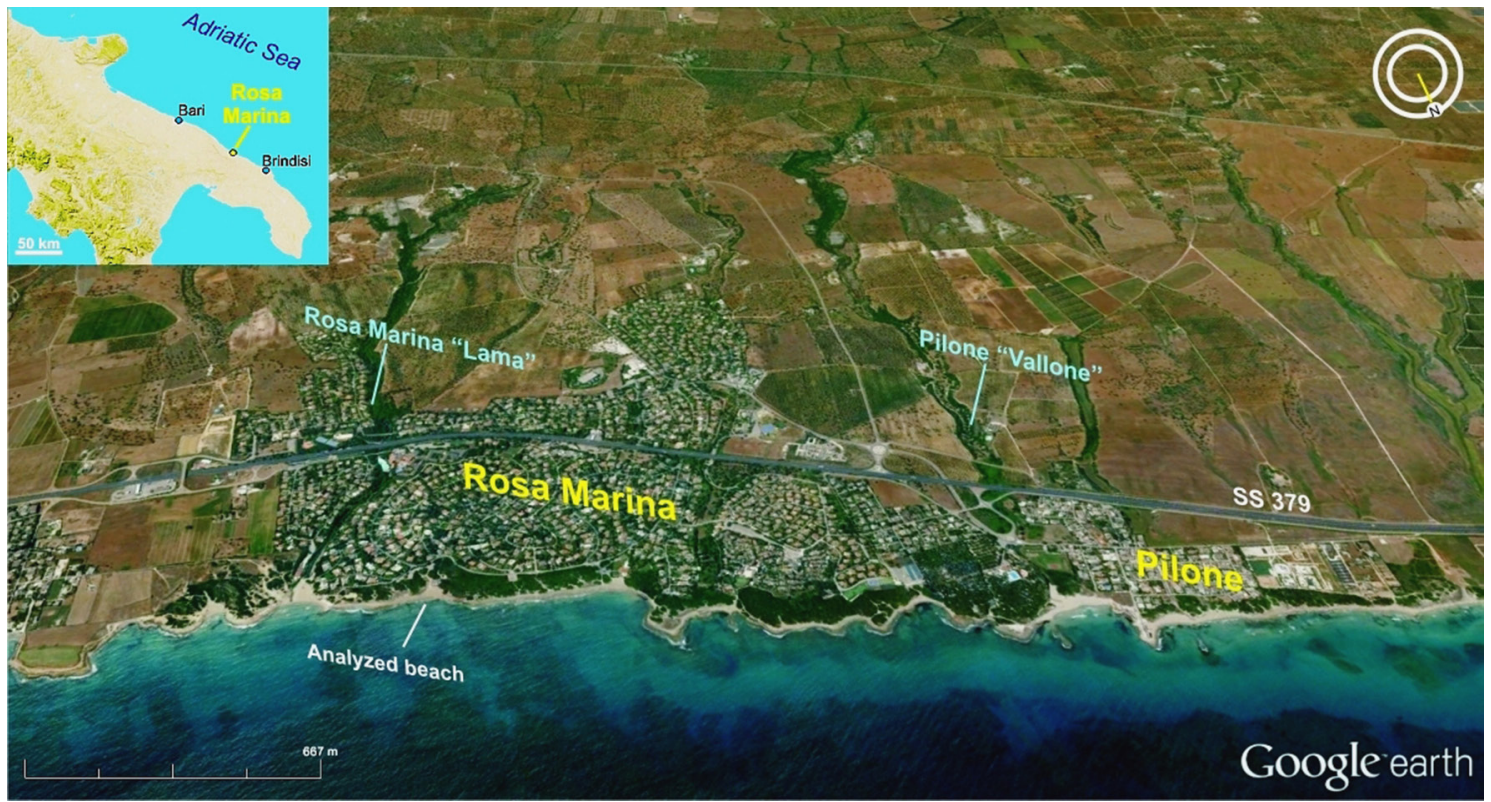

Fig. 1. Location of the study area $\left(\mathrm{N} 40^{\circ} 50^{\prime}, \mathrm{E} 17^{\circ} 50^{\prime}\right)$. Rosa Marina is situated along the Adriatic coast between Bari and Brindisi. It is the site of a large tourist complex. Note the presence of two narrow stream incisions ('Lama' and 'Vallone' are two Italian terms for 'stream').

the coast becomes more irregular with rocky areas representing local headlands. Some sandy pocket beaches (narrow beaches between two headlands) with inactive and/or erosion-affected rows of dunes are preserved.

According to the Regional Plan of Coasts (Puglia Region, 2012), the coastal area under study is characterised by intense urbanization; direct interventions on the coast concerned, however, only a transverse barrier at the mouth of the 'Rosa Marina Lama' stream and a short breakwater pier in the same area. Phenomena of coastal erosion have been reported in Annese et al. (2003) for the Torre Canne area (about $7 \mathrm{~km}$ north of Rosa Marina), whereas the shorelines were stable in the Pilone area (Fig. 1) (Puglia Region, 2006).

The geological setting (Fig. 2) of this area has been described in detail (Ciaranfi et al., 1988; Mastronuzzi et al., 2001). Nevertheless, a preliminarily, short geological and sedimentological survey was carried out in the study area. It was focused on the recognition of the main outcropping sedimentary units, the location of their stratigraphic boundaries with reference to the average sea level, the lateral variations in their facies and/or thickness, and their state regarding erosion (Fig. 2). All the outcropping sedimentary units have been sampled for petrographical analysis. The Calcarenite di Gravina Formation (Pliocene - Early Pleistocene) is the oldest sedimentary unit cropping out in this area. It represents the substratum of a succession of marine terraced units deposited during the Middle
Pleistocene to Holocene (Ciaranfi et al., 1988). The Calcarenite di Gravina Fm. is present almost continuously along the entire coast of the study area, though mostly below sea level, where it is abraded by storm waves (GRA, Fig. 2A). In this area, the Calcarenite di Gravina Fm. is made up of thick beds of medium- and coarse-grained calcarenite, with intense bioturbation and a high content of bioclasts (mostly red algae) (Moretti et al., 2011).

On top of the Calcarenite di Gravina Fm., a thin red soil unit has been recognised over a continental erosional surface, approximately at sea level (TR, Figs 2A, B): it passes upwards and laterally into marly limestones (C1). Unit C1 is made up of parallel-laminated, fine-grained limestones with abundant ostracods and with rare clay chips of red soils. On top of the TR and C1 units, a coarse-grained calcarenite unit crops out, a few centimetres above sea level (C2, Figs 2A, B). It is made up of parallel-laminated calcarenites to calcirudites with a high bioclast content (mainly fragments of bivalves and gastropods). Laterally, close to the 'Rosa Marina Lama' stream, unit C2 passes into a calcirudite (unit CR) with some gastropod remains and abundant pebbles of micritic limestone and calcarenite (Figs 2A, C).

Between 10 and $30 \mathrm{~cm}$ above sea level, overlying older units, an arenaceous unit (E1) crops out (Figs $2 \mathrm{~A}, \mathrm{C}$ ). It is made up of well-sorted sand/sandstone alternations with high-angle cross-lamination; the sands have a mixed composition, with quartz and carbonates in almost similar percentages. The top- 
most outcropping unit is sandy; its base is situated $40 \mathrm{~cm}$ to $2 \mathrm{~m}$ above sea level. It is a subrecent aeolian unit (E2), representing a coastal dune that is no longer active nowadays, but instead exposed to strong erosion (Figs 2A, C).

The succession described above represents the result of interaction between the slow uplift of the Apulian Foreland and sea-level changes. The informal units, TR, C1, C2 and E1, are considered to have been deposited on top of the Gravina Calcarenite, during a transgressive/regressive cycle, recorded by units of coastal lagoon/backshore sediments (TR and (1), passing upwards into shoreface transgressive deposits (C2, laterally fed by the terrigenous carbonates supplied by the 'Rosa Marina Lama' stream, CR). The aeolian unit (E1) represents the regressive part of the succession: it is considered to have been deposited in this area, as in many other coastal areas of the Apulian Foreland, during the middle Holocene (about 6,000 years ago: Mastro-
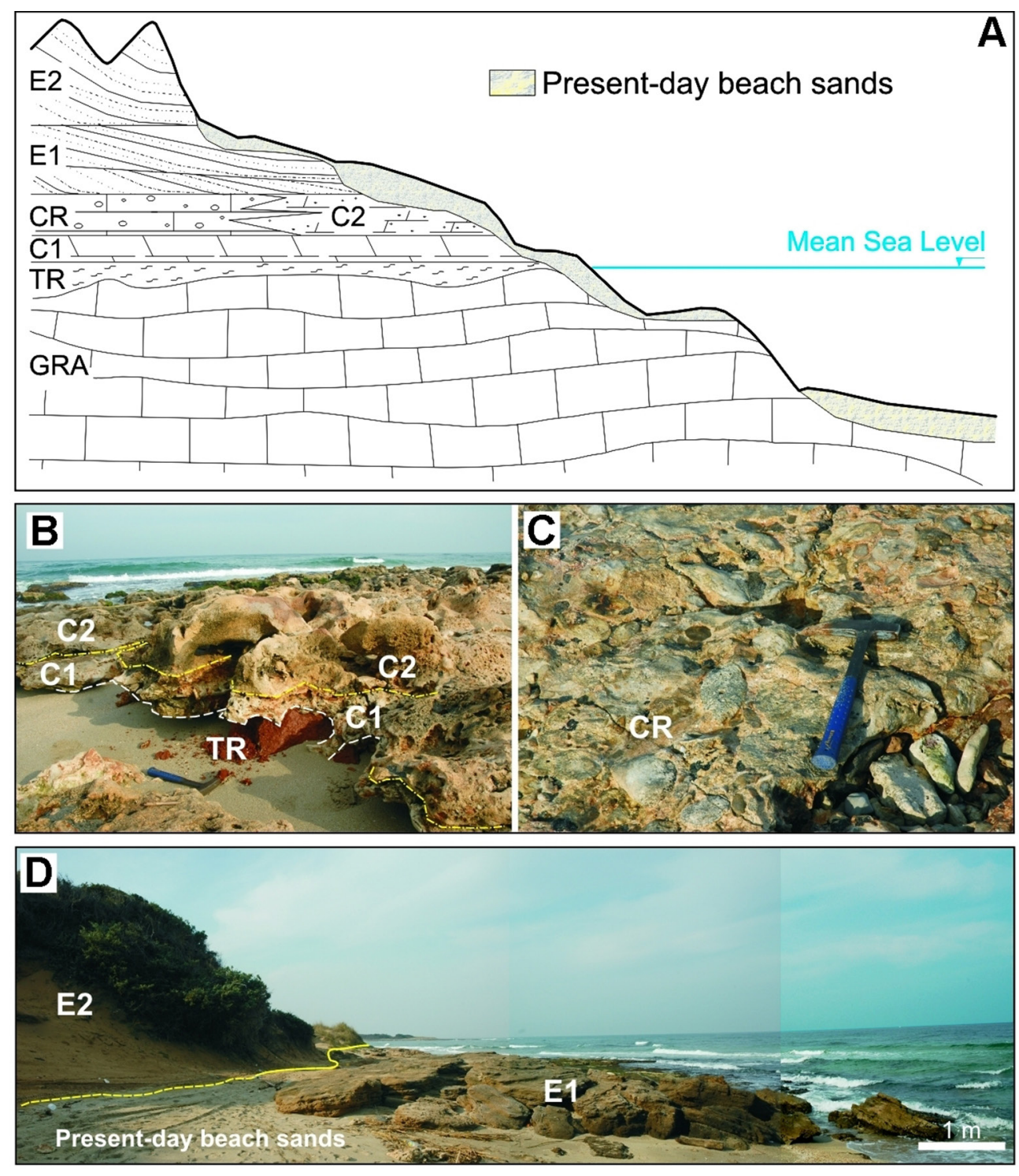

Fig. 2. Geology of the Rosa Marina area.

A - Schematic stratigraphy of the Rosa Marina area. See the text for the complete names and ages of the sedimentary units; B - Stratigraphical contact (in white) between the red soil unit (TR, at the bottom) and the overlying lagoonal calcarenite (C1). The yellow line indicates the contact between the lagoonal unit (C1) and the overlying transgressive calcarenite (C2); C - Macroscopic features of the of the calcirudite unit (CR), which passes laterally to the C2 calcarenites; D - Contact between the middle Holocene aeolian unit (E1) and the overlying younger dune (E2). Note that, on the foreground, unit E1 undergoes considerable erosion, with localized falls and block rotation; in the background, unit E2 is directly exposed to wave erosion. 
nuzzi et al., 2001; Mastronuzzi \& Sansò, 2002). The more recent coastal dune E2, however, was presumably deposited during the late Holocene (Mastronuzzi et al., 2001).

\section{Methodology}

The sands of the present-day beach were sampled in both emerged and submerged areas (Fig. 3): (1) in the shoreface, along a transect perpendicular to the coast, from the shoreline to a depth of $6 \mathrm{~m}$ (the local storm-wave base), and (2) in the backshore and foreshore, where sand samples were taken every $5 \mathrm{~m}$ from the shoreline, taking care to sample both the ordinary and winter berms (in lateral and less frequented areas) until the base of the E2 aeolian sands. A biological survey was carried out through diving at the investigated depth (up to -6 $\mathrm{m}$ ) and through sampling of organisms from both the sandy and the hard substratum.

The samples for the sedimentological analyses were collected by driving a cylinder sampler, which was tightly closed in order to avoid loss of finer sediments. In the laboratory, the samples were washed with distilled water, dried and weighed. They were processed with hydrogen peroxide and subsequently passed through a 0.063 $\mathrm{mm}$ sieve in order to determine the percentage of organic matter and fine sediment (both present in negligible percentages). The results were processed with the Gradistat v8 software (Blott \& Pye, 2001), which yielded distribution histograms, cumulative curves, and the automatic evaluation of the following textural parameters: median grain size $\left(D_{50}\right)$, sorting (sg), skewness (Sk) and kurtosis (Kg). In order to obtain ecological data, all bioclasts (shells or fragments of shells) were separated from the remainder of the sedimentary particles and placed in special Petri dishes using a binocular optical microscope. All sedimentary units cropping out in the study area were also sampled and studied petrographically for comparison in order to obtain more information on the role of erosion of the local substratum as a source for the present-day beach sands. First, the qualitative composition of beach sands was obtained with the help of a binocular optical microscope. More quantitative analyses of the present-day beach sands were carried out after the epoxy resin impregnation of the present-day beach sands and obtaining slabs for thin sections; five thin sections (covering both emerged and submerged sub-environments) were analysed, and high-resolution microscope photos were taken using low magnifications ( $x 1$ and $x 2)$. The raster images that were thus obtained were imported into image-analysis freeware (ImageJ, version 1.49) with the help of which it was possible to recognise, select and draw individual grains and to assign them to different compositional classes.

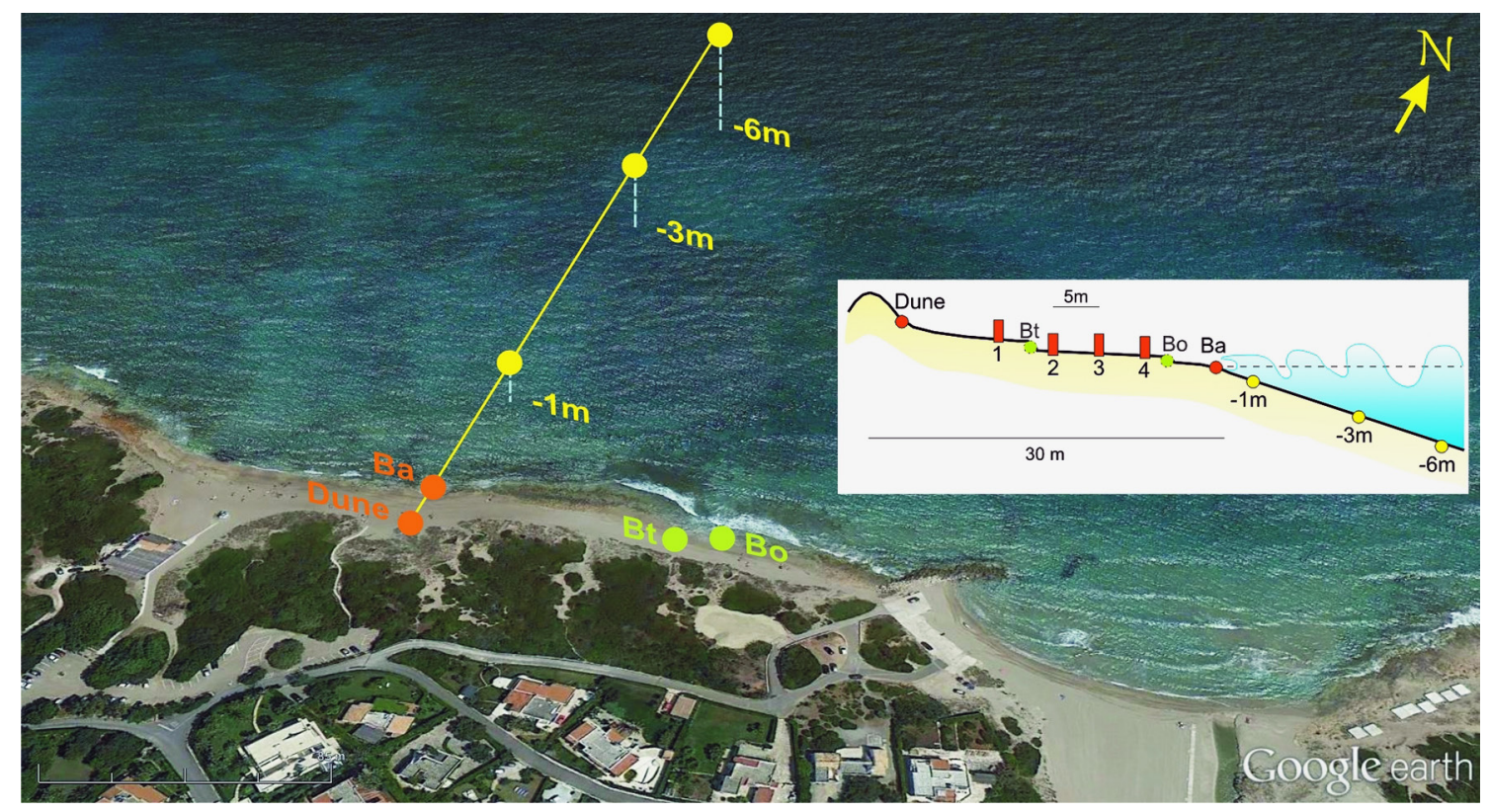

Fig. 3. Locations of the sampling stations. In the backshore (Ba), samples $1-4$ are located at 20, 15, 10 and $5 \mathrm{~m}$ from the swash zone, respectively. Sample 'dune' was collected at the base of the E1 dune unit, whereas samples Bo and Bt (ordinary and winter berm) were collected laterally (to the south-east of the transect) in an area of the beach where such morpho-sedimentary steps were still recognisable. 


\section{Grain-size analysis}

The present-day beach sediments are, from a granulometric point of view, medium- to coarsegrained sands (Table 1 and Fig. 4).

Typically, relatively high $\mathrm{D}_{50}$ values were found for the berms; the values decrease in the shoreface environments with increasing water depth (Fig. 5). No bars or sediment accumulation areas have been detected in the the submerged sectors (Fig. 5). The sands are mostly well-sorted; sorting decreases with water depth. The skewness is equal to zero on the shoreline (Fig. 3) and negative on the backshore profile, resulting in a tail of coarse material (mean left of the median); at the same points, $\mathrm{Kg}$ (i.e., the ratio between the width of the central part of the diagram and that of the tail) shows high values (leptokurtic type), except for sample Bt (curve of the platykurtic type).

The grain-size parameters can be used also for obtaining (essentially qualitative) information on the evolution of a beach with particular reference to the susceptibility to erosion (Dal Cin, 1969).

Table 1. Grain-size parameters determined for the samples from the beach sands.

\begin{tabular}{|c|c|c|c|c|c|c|c|}
\hline Sample & $\begin{array}{c}\mathrm{D}_{50} \\
(\mu \mathrm{m})\end{array}$ & $\begin{array}{l}\text { Sorting } \\
(\sigma \varphi)\end{array}$ & Description & $\begin{array}{l}\text { Skewness } \\
(\operatorname{Sk} \varphi)\end{array}$ & Shape & $\begin{array}{c}\text { Kurtosis } \\
(\mathrm{Kg})\end{array}$ & Shape \\
\hline dune (E2) & 399.695 & 0.470 & $\begin{array}{l}\text { medium sand, } \\
\text { well sorted }\end{array}$ & 0.568 & $\begin{array}{l}\text { tail to the fine } \\
\text { fraction }\end{array}$ & 1.676 & strongly leptokurtic \\
\hline 1 & 417.618 & 0.365 & $\begin{array}{l}\text { medium sand, } \\
\text { well sorted }\end{array}$ & 0.051 & symmetrical & 2.482 & strongly leptokurtic \\
\hline winter berm (Bt) & 782.277 & 0.498 & $\begin{array}{l}\text { coarse sand, } \\
\text { well sorted }\end{array}$ & 0.562 & $\begin{array}{l}\text { tail to the fine } \\
\text { fraction }\end{array}$ & 0.631 & strongly leptokurtic \\
\hline 2 & 422.702 & 0.416 & $\begin{array}{l}\text { medium sand, } \\
\text { well sorted }\end{array}$ & -0.006 & symmetrical & 2.636 & strongly leptokurtic \\
\hline 3 & 433.633 & 0.577 & $\begin{array}{l}\text { medium sand, } \\
\text { moderately well } \\
\text { sorted }\end{array}$ & -0.299 & $\begin{array}{l}\text { tail to the } \\
\text { coarse fraction }\end{array}$ & 2.446 & strongly leptokurtic \\
\hline 4 & 429.620 & 0.302 & $\begin{array}{l}\text { medium sand, } \\
\text { very well sorted }\end{array}$ & -0.292 & $\begin{array}{l}\text { tail to the } \\
\text { coarse fraction }\end{array}$ & 1.77 & strongly leptokurtic \\
\hline ordinary berm (Bo) & 800.881 & 0.467 & $\begin{array}{l}\text { coarse sand, } \\
\text { well sorted }\end{array}$ & 0.579 & $\begin{array}{l}\text { tail to the fine } \\
\text { fraction }\end{array}$ & 1.737 & strongly leptokurtic \\
\hline backshore (Ba) & 838.784 & 0.155 & $\begin{array}{l}\text { coarse sand, } \\
\text { very well sorted }\end{array}$ & 0 & symmetrical & 0.738 & platykurtic \\
\hline$-1 \mathrm{~m}$ & 392.986 & 0.576 & $\begin{array}{l}\text { medium sand } \\
\text { moderately to } \\
\text { well sorted }\end{array}$ & 0.319 & $\begin{array}{l}\text { tail to the very } \\
\text { fine fraction }\end{array}$ & 0.836 & platykurtic \\
\hline$-3 m$ & 397.568 & 0.825 & $\begin{array}{l}\text { medium sand, } \\
\text { moderately to } \\
\text { well sorted }\end{array}$ & -0.040 & symmetrical & 0.847 & platykurtic \\
\hline$-6 m$ & 249.487 & 0.662 & $\begin{array}{l}\text { medium sand } \\
\text { moderately to } \\
\text { well sorted }\end{array}$ & -0.558 & $\begin{array}{l}\text { tail to the very } \\
\text { coarse fraction }\end{array}$ & 0.850 & platykurtic \\
\hline
\end{tabular}

Table 2. Grain-size parameters determined for the adjacent Pilone beach.

\begin{tabular}{|c|c|c|c|c|c|c|c|c|}
\hline Sample & $\begin{array}{c}\text { Sampling } \\
\text { depth }\end{array}$ & $\mathrm{D}_{50}(\varphi)$ & $\begin{array}{l}\text { Sorting } \\
(\sigma \varphi)\end{array}$ & Description & $\begin{array}{c}\text { Skew- } \\
\text { ness } \\
(\mathrm{Sk} \varphi)\end{array}$ & Shape & $\begin{array}{c}\text { Kurtosis } \\
(\mathrm{Kg})\end{array}$ & Shape \\
\hline $\begin{array}{l}2006 \\
\text { 3_15_7 }\end{array}$ & +1.39 & 1.56 & 0.39 & $\begin{array}{l}\text { medium sand, } \\
\text { well sorted }\end{array}$ & 0 & symmetrical & 0.93 & mesokurtic \\
\hline $\begin{array}{l}2006 \\
3 \_15 \_8\end{array}$ & +0.58 & 1.85 & 0.48 & $\begin{array}{l}\text { medium sand, } \\
\text { well sorted }\end{array}$ & 0.03 & symmetrical & 1.04 & mesokurtic \\
\hline $\begin{array}{l}2006 \\
\text { 3_15_15 }\end{array}$ & -2.90 & 2.08 & 0.43 & $\begin{array}{l}\text { fine sand, } \\
\text { well sorted }\end{array}$ & -0.07 & symmetrical & 1.33 & leptokurtic \\
\hline $\begin{array}{l}2006 \\
\text { 3_15_16 }\end{array}$ & -4.58 & 2.27 & 0.32 & $\begin{array}{l}\text { fine sand, very } \\
\text { well sorted }\end{array}$ & 0.09 & symmetrical & 1.54 & strongly leptokurtic \\
\hline
\end{tabular}




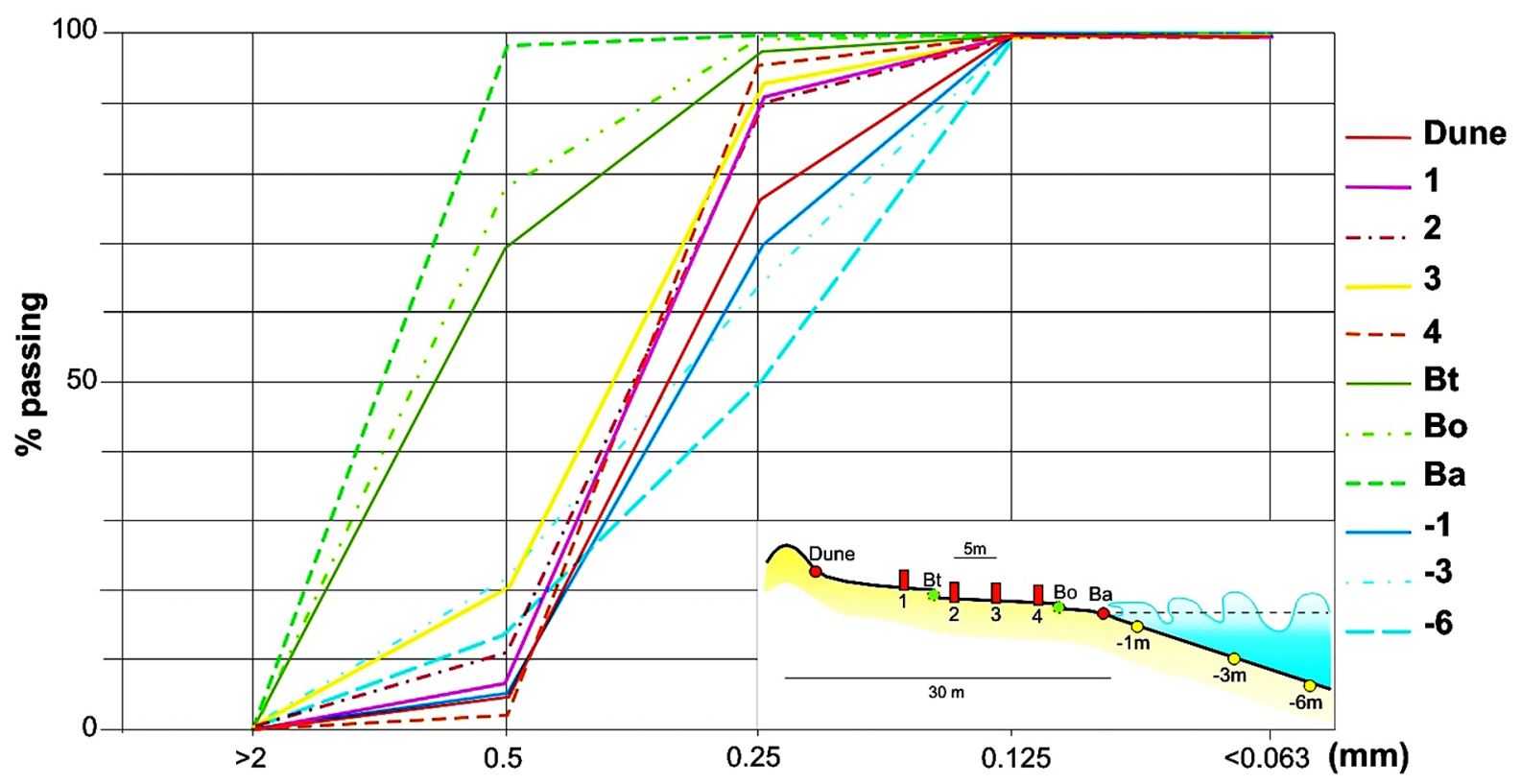

Fig. 4. Cumulative grain-size curves of the samples from the Rosa Marina beach.

Fig. 5. Variation of $D_{50}$ from the backshore to the lower shoreface/offshore transition. Note the increase in grain size in the backshore, for both the ordinary and the winter berm.

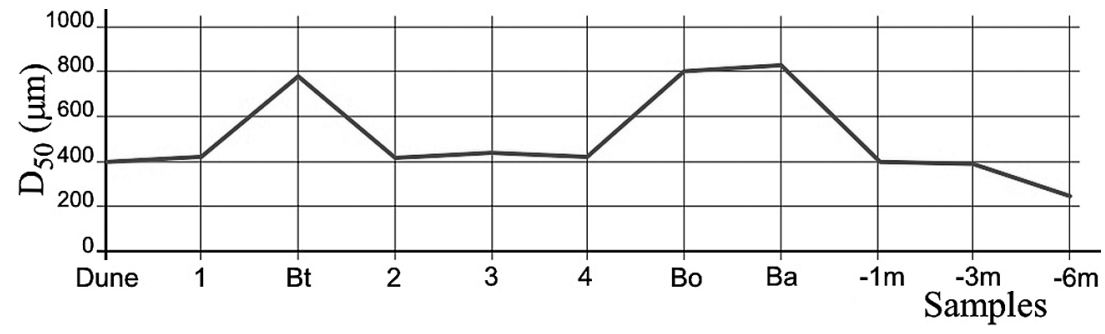

Samples from the beach of Rosa Marina commonly show values of the various textural parameters which indicate an erosional-regressive evolutionary trend: (1) sorting is clear in the backshore-foreshore-shoreface sectors; (2) Sk is mainly negative (it is a clear record of severe storm-wave hydrodynamics); (3) the distribution curves are often leptokurtic or even very leptokurtic, with tails shifted mostly toward the coarse-grained material.

Of course, more reliable data might have been obtained if samples had been collected repeatedly throughout a year, and preferably during several years. Reference data with which our data can be compared are available, however, for adjacent areas (Pilone beach resort: Fig. 1); data are taken from the Puglia Region (2006): see Table 2. The Pilone beach is located in a stable (or relatively less erosional) coastal sector showing sub-symmetric distributions (Sk about 0) and mesokurtic to leptokurtic curves (Table 2). These data confirm the erosional trend established for the Rosa Marina area.

\section{Petrographical analysis}

\subsection{The beach sands}

The petrography of the beach sands was analysed for different size fractions in order to reveal the percentages of bioclastic particles and any variations in the composition and/or concentration of specific minerals in the various granulometric classes. First the bioclast content was determined quantitatively (the quality is discussed in Section 5.2). The bioclasts were weighted and their total fraction was calculated as the percentage of the total sample weight (Table 3).

The bioclast percentage by volume was calculated using a simple conversion. Siliciclastic particles and carbonate particles have more or less the same density: the quartz grains have a density of $2.66 \mathrm{~g} \cdot \mathrm{cm}^{-3}$ whereas that of the carbonates is about $2.70 \mathrm{~g} \cdot \mathrm{cm}^{-3}$. Bioclastic carbonates can, however, have different densities (Schlager, 2005) according to their composition $\left(2.94 \mathrm{~g} \cdot \mathrm{cm}^{-3}\right.$ for aragonite; $2.72 \mathrm{~g} \cdot \mathrm{cm}^{-3}$ for calcite; $2.89 \mathrm{~g} \cdot \mathrm{cm}^{-3}$ for dolomite), 
Massimo Moretti et al.

Table 3. Bioclast/lithoclast percentages (in weight and volume) in the beach sand.

\begin{tabular}{lcccc}
\hline \multicolumn{1}{c}{ Sample } & $\begin{array}{c}\text { Bioclasts } \\
(\% \text { weight })\end{array}$ & $\begin{array}{c}\text { Lithoclasts } \\
(\% \text { weight })\end{array}$ & $\begin{array}{c}\text { Bioclasts } \\
\left(\% \mathrm{~V}_{\text {max }}\right)\end{array}$ & $\begin{array}{c}\text { Lithoclasts } \\
\left(\% \mathrm{~V}_{\text {min }}\right)\end{array}$ \\
\hline dune (E2) & 0.74 & 99.26 & 1.00 & 99.00 \\
1 (20 m from the shoreline) & 1.98 & 98.02 & 2.67 & 97.33 \\
2 (15 m from the shoreline) & 4.71 & 95.29 & 6.35 & 93.65 \\
3 (10 m from the shoreline) & 3.05 & 96.95 & 4.11 & 95.89 \\
4 (5 m from the shoreline) & 3.04 & 96.96 & 4.10 & 77.90 \\
ordinary berm (Bo) & 16.84 & 83.16 & 22.73 & 26.32 \\
swash zone $(\mathrm{Ba})$ & 54.58 & 45.42 & 1.43 & 98.57 \\
$-1 \mathrm{~m}$ & 1.06 & 98.94 & 3.27 & 96.73 \\
$-3 \mathrm{~m}$ & 2.42 & 97.58 & 15.34 & 84.66 \\
\hline$-6 \mathrm{~m}$ & 11.36 & 88.64 & & \\
\hline
\end{tabular}

and the structure of the shells and other fragments of marine organisms usually have a varying but relatively high porosity (intraparticle porosity of Choquette \& Pray, 1970), resulting in a total bulk volume that varies from a maximum value of 2.7 $\mathrm{g} \cdot \mathrm{cm}^{-3}$ (porosity $=0$ ) to a minimum of $2.0 \mathrm{~g} \cdot \mathrm{cm}^{-3}$ (Jackson \& Richardson, 2007). To obtain the maximum volume percentage of the bioclasts (the maximum difference from the percentages calculated considering their weight: Table 3), we considered the bulk density of the more porous skeletal material (the "unfilled shells" of Choquette \& Pray, 1970).

The bioclast content in the backshore and foreshore is low, but it increases linearly from the dune to the shoreline, where it becomes predominant (Table 3); in the shoreface it increases with water depth. The bioclast content varies in the different grain-size fractions, but the shells and fragments of shells are most characteristic of the coarse fractions (>500 $\mu \mathrm{m})$.

The lithoclasts of the beach sands (Fig. 6) consist mainly of carbonates, quartz and other minerals that are present in negligible percentages (such as pyroxene and feldspar); there are also rare frag- ments of siliciclastic rocks and of anthropogenic material (Fig. 6B, C).

The carbonate lithoclasts predominate in the terrigenous portion of the sands. They are monomineralic fragments of older rocks (micritic limestones and rarely calcarenites) and polymineralic lithoclasts of calcite together with other minerals. The second component in the beach sands is quartz. It is almost exclusively crystalline quartz and only rarely chert or chalcedony. The quartz grains always are well rounded (Fig. 7B). Furthermore, some rare feldspars are present in the form of potassium feldspar or plagioclase. The potassium feldspar grains (mainly microcline) contain inclusions (zircon and plagioclase: Fig. 7C) and show alteration rims in the form of clay minerals (Fig. 7D). The dark-coloured minerals consist mainly of pyroxene (Fig. 7E), which shows up light green under crossed nichols and yellowish under parallel nichols; they often are well rounded and they may contain inclusions of volcanic glass (Fig. 7E). The quantitative data on the composition of these sands come from the image analysis (Fig. 8): three main compositional classes of sands (carbonates, quartz and other minerals)
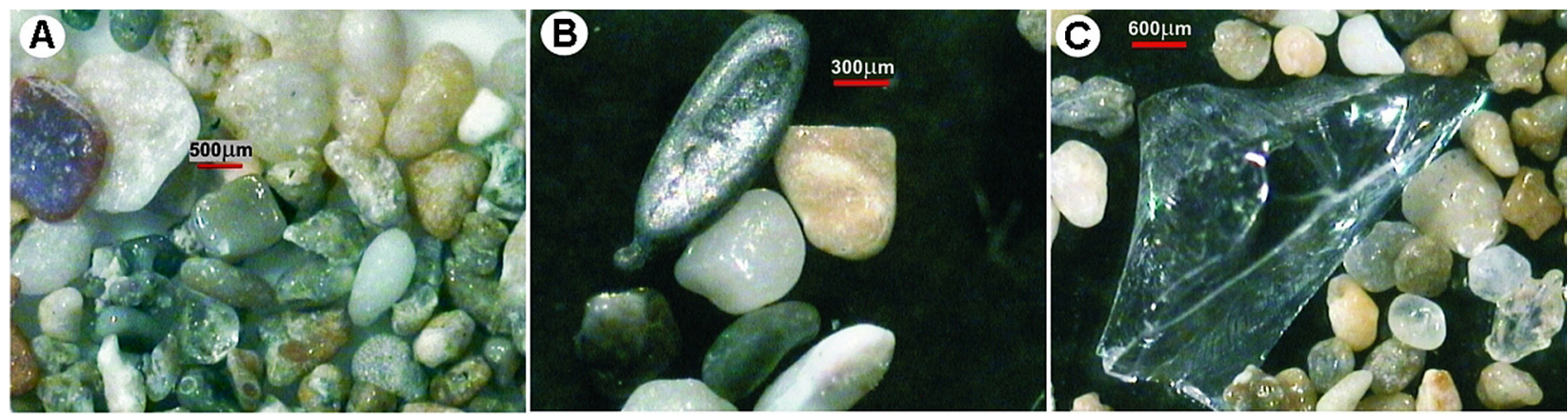

Fig. 6. Petrographical features of the Rosa Marina sands observed with an optical binocular microscope.

A - Grains with a diameter of $>500 \mu \mathrm{m}$ : limestone lithoclasts and several rounded quartz grains; B - Piece of polished metal from some jewelry (earring, necklace?); C - Large fragment of transparent glass (from a bottle). 
Fig. 7. Petrographical features of the Rosa Marina sands in thin section. A - Sands with a mixed composition (mainly carbonates and quartz). Large fragments of red algae are clearly visible in the carbonate fraction (crossed nichols); B - Grains of calcite and well rounded quartz; the quartz grains with magmatic loops are derived from volcanic rocks (crossed nichols); C - Microcline (K-feldspar) grain with inclusions of zircon $(\mathrm{Zr})$ and plagioclase $(\mathrm{Pl})$ (crossed nichols); D - Microcline twinning albite and pericline (crossed nichols); E - Yellow-greenish pyroxene with an inclusion of volcanic glass (parallel nichols).
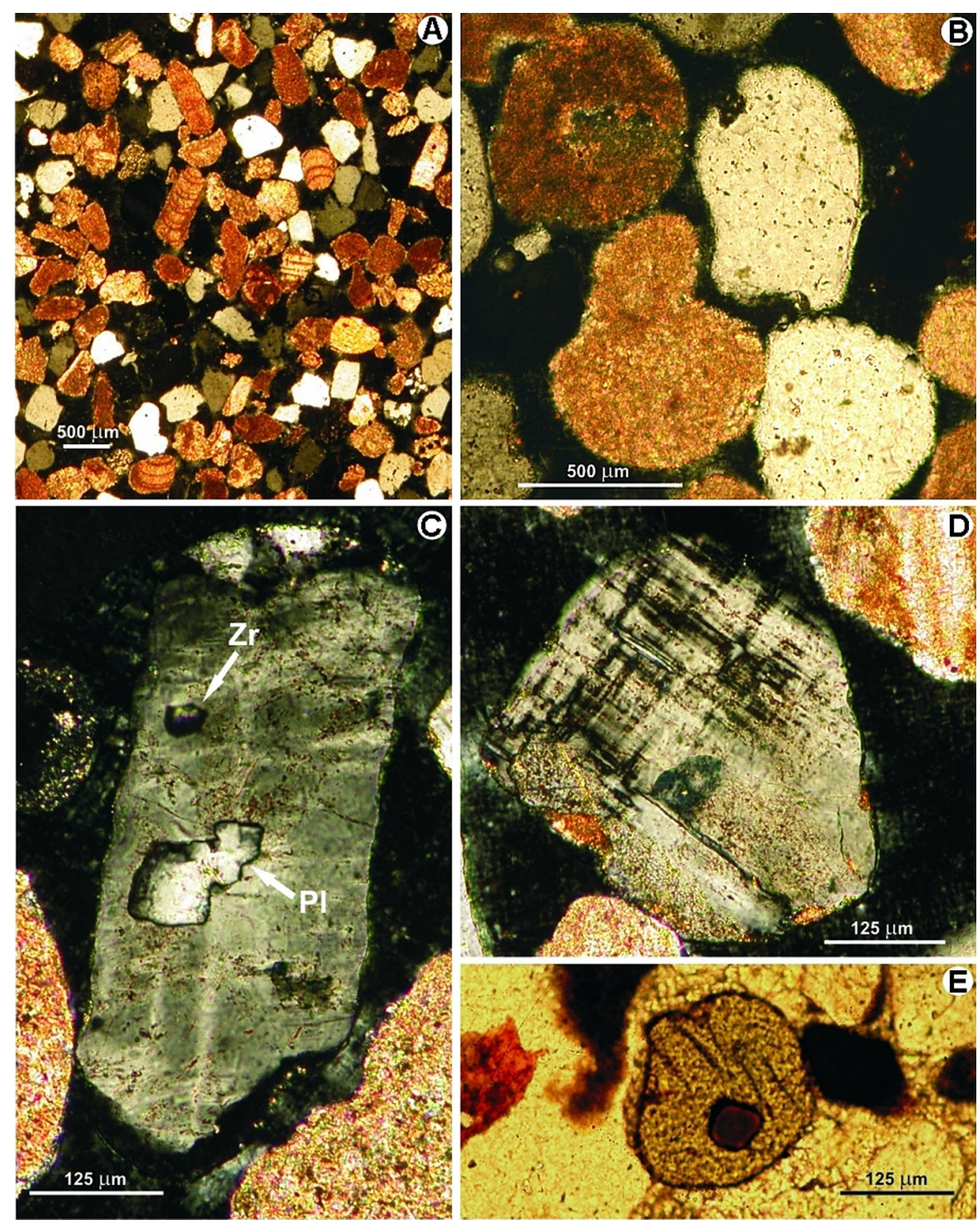

have been recognised. The values obtained using ten different photos are shown in Table 4.

The classification of sands containing siliciclastic and carbonates grains (either lithoclasts or bioclasts) is related with the definition of 'hybrid sands' (Zuffa, 1980; 1985), corresponding to the 'mixed sand' of Mount (1985) and the 'miscellaneous sand' of Pettijohn (1975). Classification of the Rosa Marina mixed sands requires the recognition of the following components: (1) carbonate lithoclasts $(\mathrm{CE}=$ Carbonate Extraclasts, i.e. terrigenous carbonate particles eroded from older limestones), (2) bioclasts (B, i.e. only carbonate particles derived from present-day organisms), (3) siliciclastic particles (NCE, Non Carbonate Extraclasts, i.e. terrigenous particles eroded from non carbonate older rocks/sediments). Figure 9 shows the classification of the sands (after Folk, 1959; Zuffa, 1980; 1985; Mount, 1985; Flügel, 2004) as a function of the percentages of these components by weight (Fig. 9A) and by volume (Fig. 9B) of their bioclast content; the differences are slight. The samples can commonly be classified as carbonate extraclastic hybrid sand.

Table 4. Composition (in percentages) of the Rosa Marina sands calculated in 10 different photos. The mean values can be considered as representative (note that values do not differ significantly) and indicate relative frequencies of carbonates as $62 \%$, of quartz as $34 \%$, and of other minerals as $4 \%$. The 'other' class contains feldspar, pyroxene and other minerals that are present in negligible percentages.

\begin{tabular}{lccc}
\hline & $\begin{array}{c}\text { Carbonate } \\
(\%)\end{array}$ & $\begin{array}{c}\text { Quartz } \\
(\%)\end{array}$ & $\begin{array}{c}\text { Other } \\
(\%)\end{array}$ \\
\hline 1 & 59.33 & 36.42 & 4.25 \\
2 & 62.06 & 32.73 & 5.21 \\
3 & 63.24 & 33.4 & 3.36 \\
4 & 63.43 & 35.35 & 1.22 \\
5 & 62.91 & 32.21 & 4.88 \\
6 & 58.05 & 37.34 & 4.61 \\
7 & 62.43 & 33.26 & 4.31 \\
\hline 8 & 61.78 & 34.86 & 3.36 \\
9 & 60.73 & 35.29 & 3.98 \\
10 & 64.67 & 33.91 & 1.42 \\
\hline Mean value & $61.86 \%$ & $34.48 \%$ & $3.66 \%$ \\
\hline
\end{tabular}




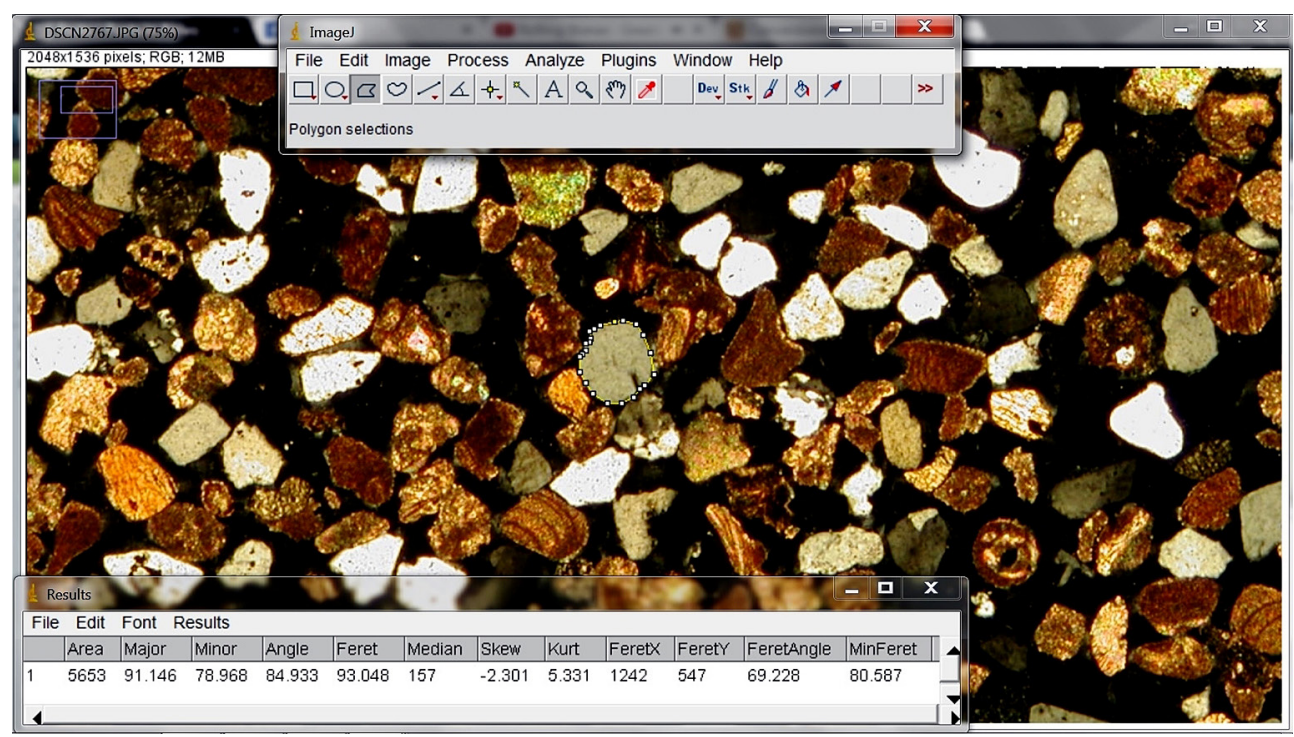

Fig. 8. Image analysis (Image J Software) screen. It contains some intuitive but powerful tools (top), allowing the selection or drawing of individual sand grains: the software directly shows the surface area, the diameter and the shape parameters of the selected grain.

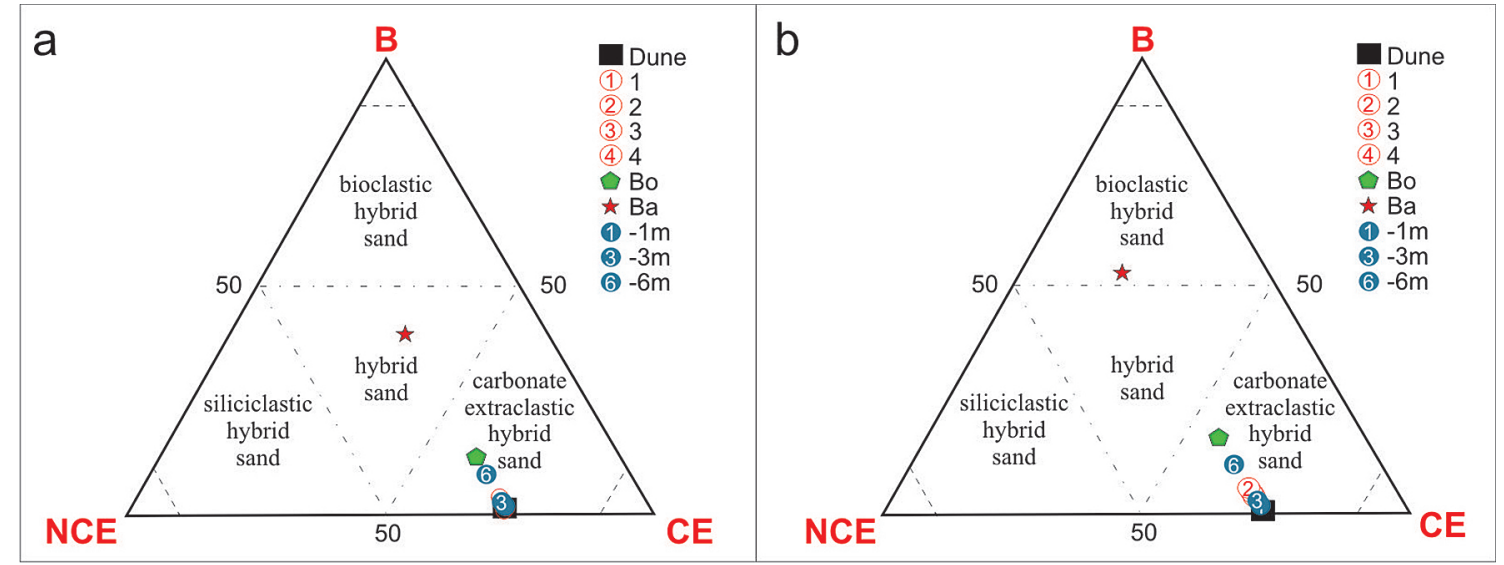

Fig. 9. Composition-based classification of the Rosa Marina sands. (NCE = Non Carbonate Extraclasts; B = bioclasts; $\mathrm{CE}=$ carbonate extraclasts). Note that the classification of the analysed samples does not depend significantly on measurement of weight or volume.

A - Percentages by weight, as determined in the laboratory; B - Percentages by volume, as obtained using the minimum bulk density for bioclasts.

Two samples, viz. Bo (ordinary berm) and the sample collected at a water depth of $6 \mathrm{~m}$, are close to the field of hybrid sand. The sample from the shoreline (Ba) has a bioclast content that classifies it as a hybrid sand if we consider the weight percentage, and as a bioclastic hybrid sand on the basis of the volume percentage.

\subsection{The older sedimentary units}

The relatively thick units along the investigated shoreline that are affected by erosion (Fig. 2) are formed by the Calcarenite di Gravina Fm. (GRA) and by the recent aeolian dunes (E1 = middle Hol- ocene and E2 = late Holocene). The Calcarenite di Gravina Fm. consists locally of a massive biocalcarenite with a packstone texture (Fig. 10A); it is made up almost entirely of red algae (with rare lithoclasts, fragments of bivalves and benthic foraminifers). The middle Holocene aeolian unit (E1, Fig. 10B) has the same petrographic characteristics as the present-day sands except for the presence of a calcite cement. Carbonate clasts (which form over $60 \%$ of the rock), quartz and some pyroxene (with petrographic characteristics very similar to those of the present-day sands) are present.

The present-day sands thus clearly show a compositional affinity with the recent aeolian-dunes (E1 and E2) and contain also numerous clasts of fossil 


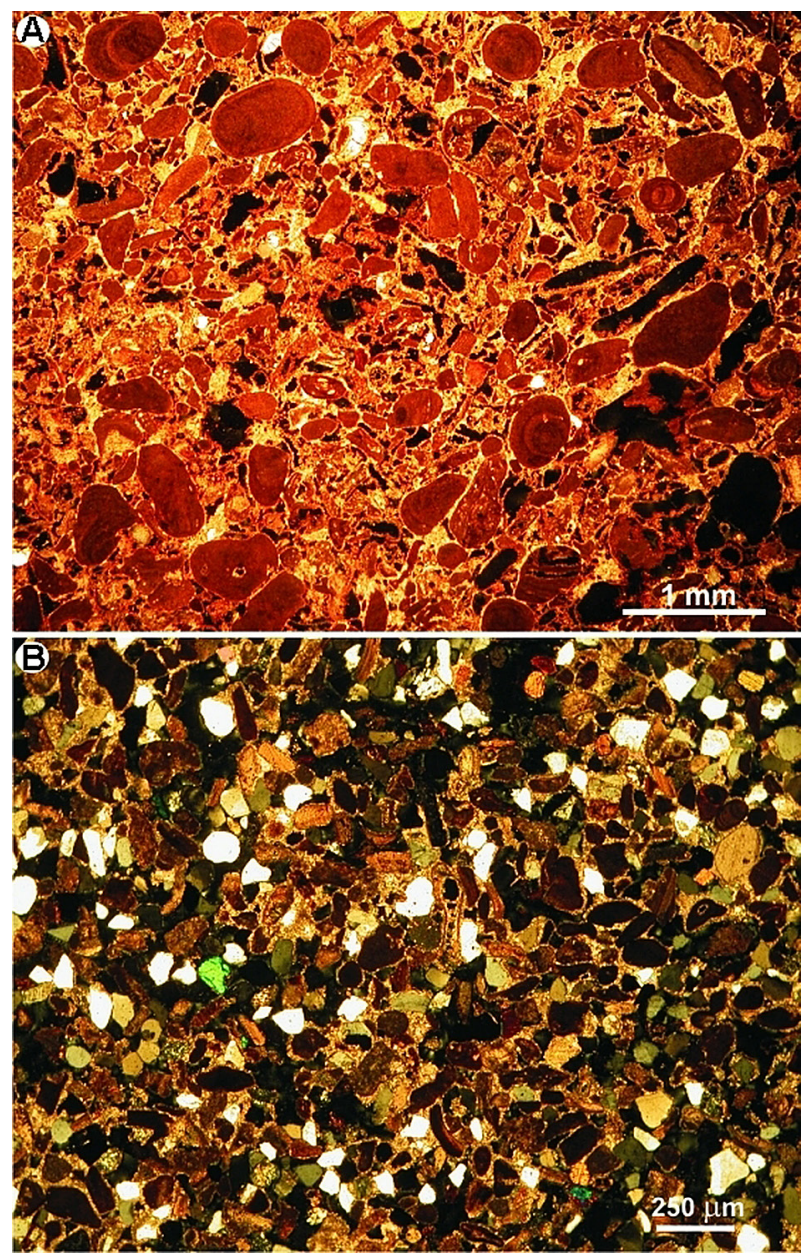

Fig. 10. Petrographical details in thin section.

A - The Calcarenite di Gravina Fm. is made up by large clasts of red algae (crossed nichols); B - The aeolian unit E1 shows the same petrographical features as the present-day beach-sands: carbonates, quartz and some feldspar and pyroxene (bright interference colours) (crossed nichols).

red algae that probably come from the Calcarenite di Gravina Fm. In other words: the lithoclast content of the Rosa Marina sands records the erosion of the thickest (and well exposed to wave action) sedimentary units in this coastal sector, showing that supply by longshore transport from other areas is not needed to explain the composition of these sands.

\section{Ecology of the beach}

The area of interest was also analysed from an ecological/biological point of view in order to obtain a clear picture of the distribution of the main biocenoses in both sandy areas and in the hard-rock substratum. Single bioclasts of organisms that con- tribute with their remains to the sands have been collected and identified (commonly at genus level). The distributions of the organisms on soft- and hard- bottom yields evidence regarding the origin of the bioclasts in terms of bathymetric and ecological zones.

\subsection{The main biocenosis}

The analysed area is situated between the supralittoral and the upper infralittoral zones (sensu Peres \& Picard, 1964); it can be divided into (1) the backshore, corresponding to the supralittoral zone; (2) the foreshore, corresponding to the mesolittoral zone; and (3) the shoreface until the wave base $(-6 \mathrm{~m})$, corresponding to the upper infralittoral zone. In all parts of the study area, soft sediment and hard substratum alternate. In the supralittoral zone, the biocenosis of the supralittoral sands is characterised by the presence of bioclastic material deposited during severe storms (algae, seagrass, remains of terrestrial plants, remains of marine and terrestrial organisms). This biocenosis alternates with that of supralittoral rocks colonized by few organisms such as gastropods of the genus Melaraphe.

In the mesolittoral zone, the upper intertidal rock contains a biocenosis that is characterised by deposits of cyanobacteria, crustaceans, barnacles like Chthamalus and gastropods such as Patella. In the lower intertidal zone, vermetids occur, indicating a priority habitat for the marine conservation in the SPA/BIO Protocol (Specially Protected Areas and Biological Diversity in the Mediterranean) of the Barcelona Convention (1997; see also Relini \& Giaccone, 2009). The facies is characterised by bioconstructions of the sessile gastropod Dendropoma petraeum that builds complexes which induce a large increase in animal biodiversity (especially annelids, molluscs, crustaceans, echinoderms, and small benthic fish) and vegetation (calcareous seaweed thallus, algal mats and leafy algae). This highly diversified habitat is particularly sensitive to oil pollution and surfactants as well as to mechanical destruction related with the harvesting of some bivalves of the genus Lithophaga.

In the infralittoral zone, the soft-sediment sea floor is locally characterised by a biocoenosis of infralittoral algae. At intermediate depths (-3 m), the bedrock is only sparsely inhabited, probably as a consequence of wave-induced erosion. At a depth of $-6 \mathrm{~m}$, the biocenosis is more diversified and characterised by encrusting and leafy algae, sponges (especially the photophilous species Chondrilla nucula, which covers large portions of the hard substratum: 


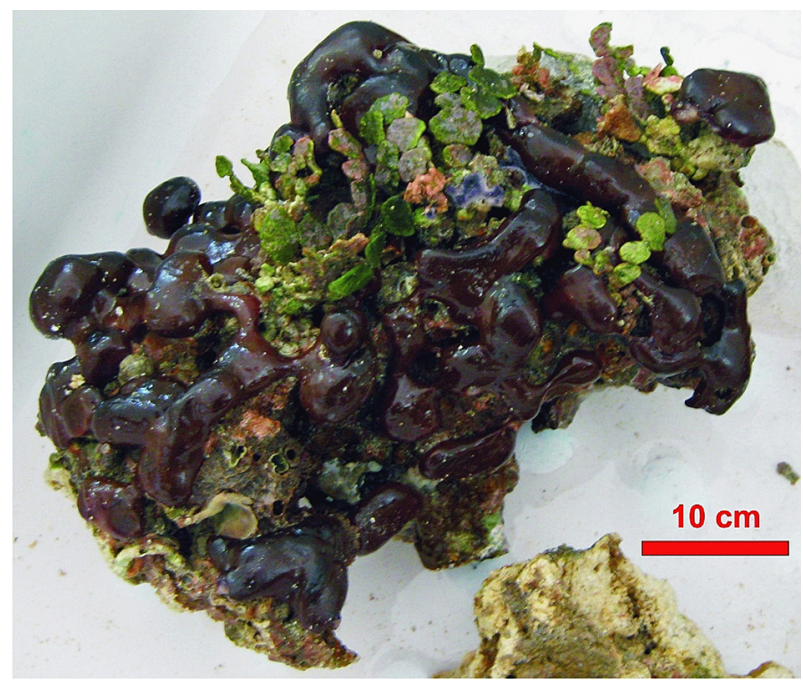

Fig. 11. Hard-bedrock sample from a depth of $-6 \mathrm{~m}$. The species Chondrilla nucula Schmidt, 1862 covers almost the whole sample. Green algae, Halimeda tuna (J.Ellis \& Solander) J.V. Lamouroux, 1816, are also well recognisable.

Fig. 11), polychaete serpulids, molluscs, vermetids and decapod crustaceans (especially hermit crabs).

\subsection{Identification of the bioclasts}

The bioclastic content (Table 4) of the beach sands has been analysed in more detail: the remains of the organisms were identified and classified, as far as possible, from a taxonomical point of view. The bioclasts consist of fragments of (1) rhizopods,
(2) mollusc shells, (3) thorns or fragments of echinoderm exoskeletons, (4) bryozoans, and (5) fragments coming from less frequent organisms (this fifth category, called "other", includes the remains of algae, spicules of sponges, fragments of serpulid pipes, fragments of barnacles and other crustaceans).

The largest contribution comes from molluscs, in particular from gastropods and bivalves, although the relative percentages are highly variable in the analysed sub-environments (Fig. 12). The number of identified mollusc taxa is 55 (Table 5, Fig. 13); the other bioclasts come from 39 taxa of gastropods (37 identified at the genus level and second-level family) and 16 taxa of bivalves (15 identified at the genus level and 1 at the level of the family). The number of taxa (Fig. 14) tends to increase gradually from the dunes (only one taxon) to the shoreline (52 taxa), to decrease again with water depth; it finally increases again at a depth of $-6 \mathrm{~m}$ (18 taxa).

The recognised mollusc taxa are not typical of a single area, but rather come from slightly different ecological and bathymetric sub-environments (Fig. 15). A conspicuous part of the molluscs (36.4\% of the total) is typical of rocky bottoms; the more frequent taxa, found at three or more sampling stations, belong to the genera Columbella (Fig. 13D) and Striarca (family Chamidae: Fig. 13H). Another large fraction $(23.6 \%$ of the total) is characteristic of sandy bottoms; the most frequent taxa (also found at three or more sampling stations) belong to the genera Caecum, Nassarius, Venericardia, and Parvicardium. Another fraction $(10.9 \%$ of the total) consists of mol-

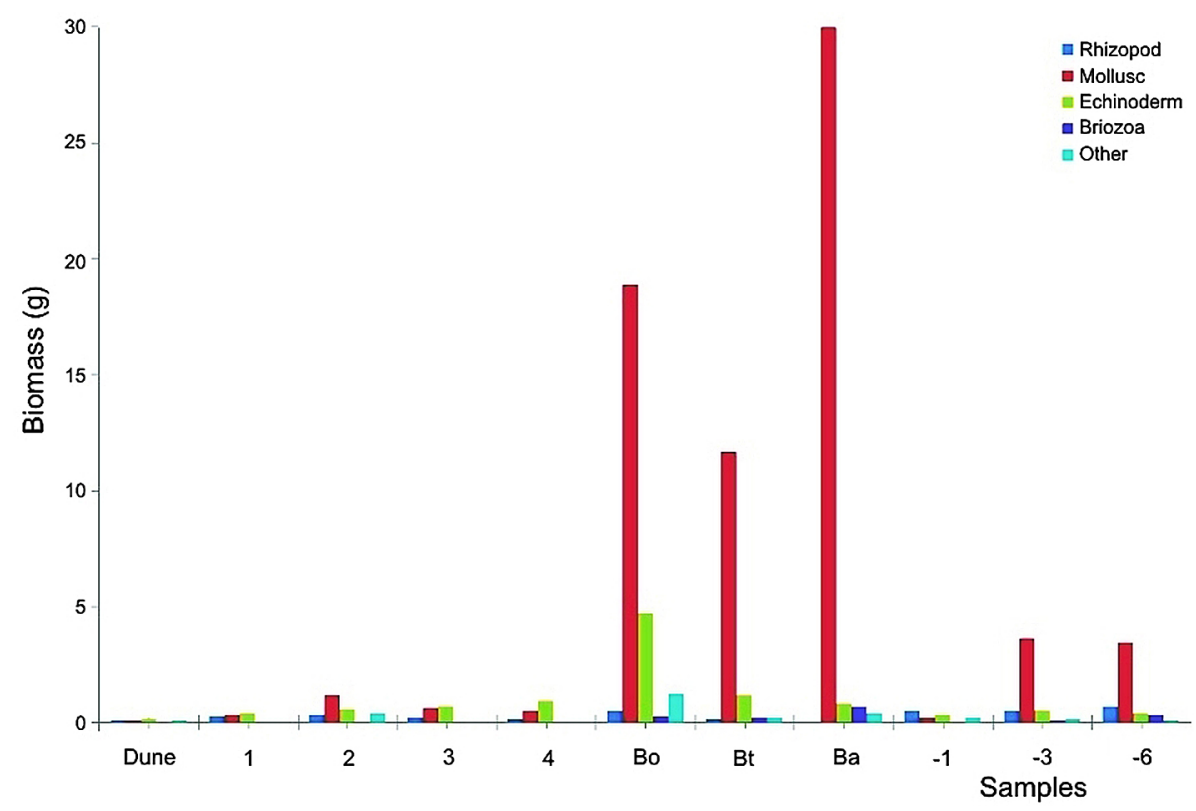

Fig. 12. Mean values of biomass (in grams) in sediments from different sectors of the beach. 
Fig. 13. Well preserved bioclasts within the Rosa Marina beach sands.

A - Bittium is the only taxon that is present in all samples; B - Gastropods of the genus Tricolia are typical of seagrass; C - Clanculus is a gastropod typical of rocky environments, particularly at at depth of at least $10 \mathrm{~m}$; D - Gastropods of the genus Columbella are characteristic of shallow rocky environments with a rich vegetation; E - Fossarus is a gastropod that commonly is found in a rocky mesolittoral zone; F - Melaraphe is a gastropod of rocky environments in the supralittoral zone; G - Gastropods of the genus Hydrobia live in brackish transitional areas; $\mathbf{H}$ - Striarca is a bivalve that is common as bioclasts in the Rosa Marina beach sands; it is typical of a rocky environment.
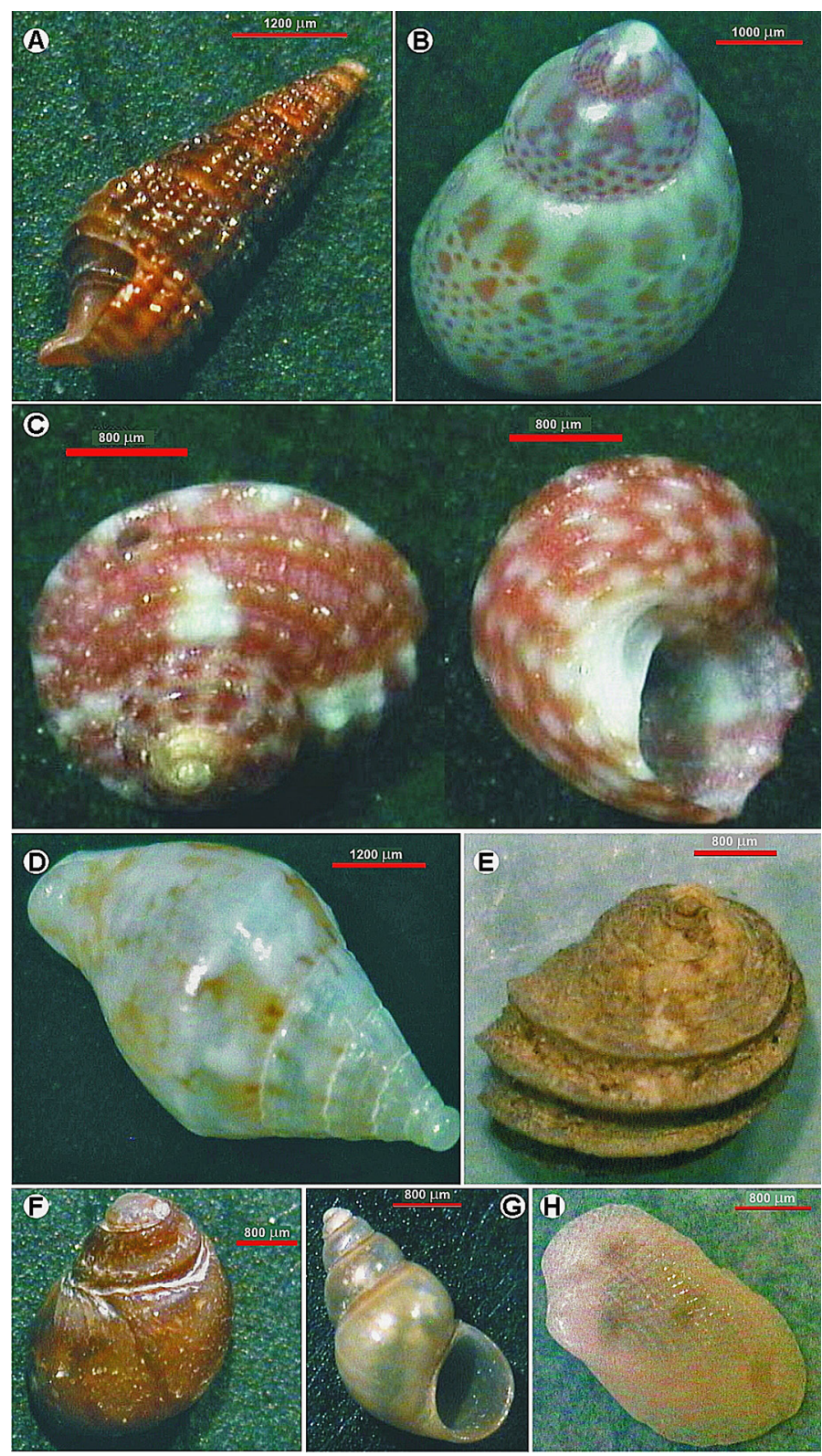

luscs that can live on both sandy and rocky bottoms. There are also seven taxa of gastropods $(12.7 \%$ of the total) that prefer to live in the grasslands of seagrass or algae. The most frequent taxa (found at three or more sampling stations) are the genera Tricolia (Fig. 13B), Jujubinus, Rissoa and Alvania. One taxon, the genus Bittium (Fig. 13A), is practically ubiquitous and can live on shallow rocky bottoms covered with vegetation, in the grasslands of marine plants and also on soft substratum. In particular, shell fragments of Bittium have been found in all analysed samples. Only two taxa (3.6\% of the total) are typical of slightly deeper environments; they are the genera Clanculus (Fig. 13C) and Irus.

Five taxa (9.1\% of the total) are parasites of gastropods or of other organisms: the genus Epitonium

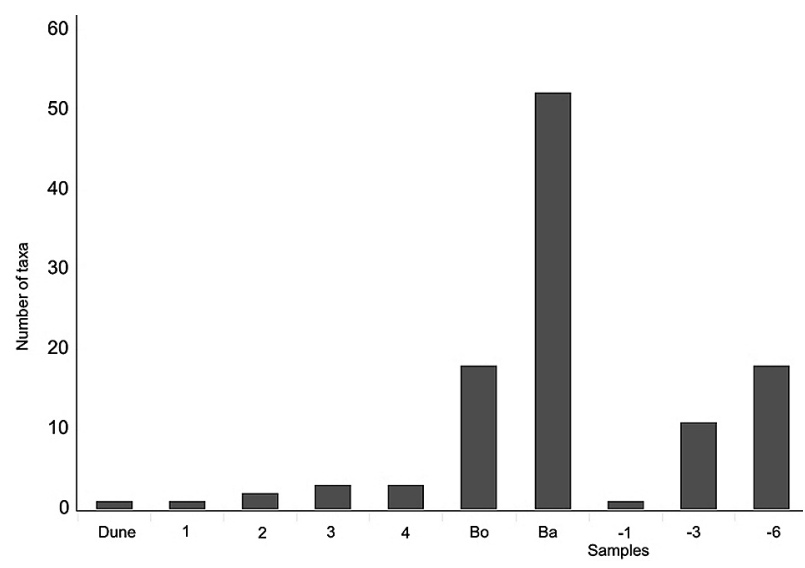

Fig. 14. Number of taxa in the various beach sub-environments. 
Table 5. Taxa identified as contributing to the bioclasts of the Rosa Marina beach sands.

\begin{tabular}{|c|c|c|c|c|c|c|c|}
\hline & 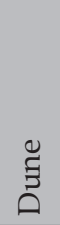 & 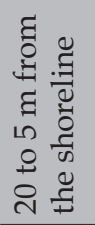 & 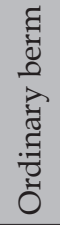 & 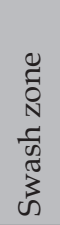 & $\begin{array}{l}\Xi \\
\neg\end{array}$ & $\begin{array}{c}q \\
\infty\end{array}$ & $\begin{array}{l}\text { I } \\
0 \\
1\end{array}$ \\
\hline \multicolumn{8}{|c|}{ Gastropods } \\
\hline Emarginula & & & & 1 & & & \\
\hline Patella & & & & 1 & & 1 & \\
\hline Melarhaphe & & & & 1 & & & \\
\hline Epitonium & & & & 1 & & & \\
\hline Pisania & & & & 1 & & & \\
\hline Pollia & & & & 1 & & & \\
\hline Tricolia & & 1 & 1 & 1 & & 1 & 1 \\
\hline Clanculus & & & 1 & 1 & & & \\
\hline Gibbula & & & 1 & 1 & & & \\
\hline Jujubinus & & & 1 & 1 & & & 1 \\
\hline Rissoa & & & 1 & 1 & & 1 & 1 \\
\hline Alvania & & 1 & 1 & 1 & & 1 & 1 \\
\hline Rissoina & & & 1 & 1 & & & \\
\hline Hydrobia & & & 1 & & & & \\
\hline Bittium & 1 & 1 & 1 & 1 & 1 & 1 & 1 \\
\hline Cerithium & & & & 1 & & & 1 \\
\hline Caecum & & & 1 & 1 & & 1 & 1 \\
\hline Vermetidae & & & & 1 & & & \\
\hline Triphoridae & & 1 & 1 & 1 & & 1 & 1 \\
\hline Melanella & & & & 1 & & & \\
\hline Muricopsis & & & & 1 & & & \\
\hline Ocinebrina & & & 1 & 1 & & & \\
\hline Hexaplex & & & & 1 & & & \\
\hline Columbella & & 1 & & 1 & & & 1 \\
\hline Nassarius & & & 1 & 1 & & & 1 \\
\hline Fusinus & & & & 1 & & & \\
\hline Neverita & & & & & & & 1 \\
\hline Gibberula & & & 1 & 1 & & & \\
\hline
\end{tabular}

is an anemones parasite, the Triphoridae family lives mainly on sponges, Melanella is typically an echinoderms parasite, the genus Odostomia is a parasite of worms and shellfish, and the genus Cerithiopsis feeds mainly on sponges that are its habitat. Finally, one taxon, the genus Hydrobia (Fig. 13G), is typical of brackish environments.

\section{Discussion}

Geomorphological and sedimentological analyses show that the Rosa Marina beach is now distinctly subjected to erosion; evidence consists of the local erosion of the coastal dunes, and the lack of detectable depositional bars in the shoreface. Moreover, the calculation of all statistical param-

\begin{tabular}{|c|c|c|c|c|c|c|c|}
\hline & $\underset{\Xi}{\tilde{\Xi}}$ & 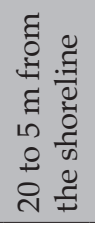 & 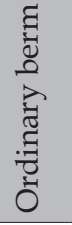 & $\begin{array}{l}0 \\
\text { D } \\
N \\
\text { हा } \\
\text { गี } \\
3 \\
\text { क }\end{array}$ & $\begin{array}{l}\Xi \\
\vec{I}\end{array}$ & $\begin{array}{l}\text { ב } \\
\text { P }\end{array}$ & $\begin{array}{l}\text { E } \\
\text { i }\end{array}$ \\
\hline Mitra & & & & 1 & & & \\
\hline Vexillum & & & & 1 & & & \\
\hline Mangelia & & & & 1 & & & \\
\hline Conus & & & 1 & 1 & & & \\
\hline Bela & & & & 1 & & & \\
\hline Raphitoma & & & & 1 & & & \\
\hline Omalogyra & & & & 1 & & & \\
\hline Odostomia & & & & 1 & & & 1 \\
\hline Cylichna & & & 1 & 1 & & & \\
\hline Fossarus & & & 1 & 1 & & & \\
\hline Cerithiopsis & & & 1 & & & & \\
\hline \multicolumn{8}{|c|}{ Bivalves } \\
\hline Arca & & & & 1 & & & \\
\hline Barbatia & & & & 1 & & & \\
\hline Striarca & & 1 & & 1 & & 1 & 1 \\
\hline Glycymeris & & & & 1 & & & \\
\hline Mytilaster & & & & 1 & & & 1 \\
\hline Loripes & & & & 1 & & & \\
\hline Cardita & & & & 1 & & & \\
\hline Glans & & & & 1 & & & \\
\hline Venericardia & & & & 1 & & 1 & 1 \\
\hline Chamidae & & & & 1 & & 1 & 1 \\
\hline Parvicadium & & & & 1 & & 1 & 1 \\
\hline Tellina & & & & 1 & & & \\
\hline Chamelea & & & & 1 & & & \\
\hline Irus & & & & 1 & & & \\
\hline Venerupis & & & & 1 & & & 1 \\
\hline Hiatella & & & & 1 & & & \\
\hline
\end{tabular}

eters regarding the grain sizes of the sediments at various places along and perpendicular to the coast indicate that the Rosa Marina area is being eroded, whereas adjacent coastal sectors seem to be more stable. The petrographical analyses of sand samples carried out with a binocular and in thin section (using also some image-analysis procedures) indicate regarding their modal composition that they are made up of calcium carbonates (about 62\%), quartz (about 34\%) and other minerals (K-feldspar, plagioclase, pyroxene, etc. constitute about $4 \%$ ). A similar petrographical composition has been found for the rocks cropping out in the coastal area showing the importance of the cannibalization processes for the recent formation and evolution of coastal deposits in the Apulian Foreland, which is consistent with regional data 


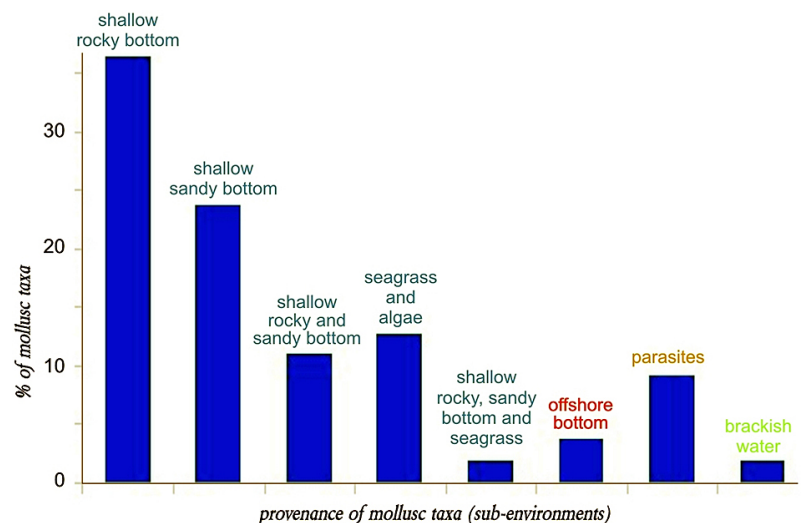

Fig. 15. Sub-environments that form source areas for the mollusk fragments in the Rosa Marina beach sands.

(Tropeano et al., 2002; Tropeano \& Spalluto, 2006; Gallicchio et al., 2014; Gioia et al., 2014). The quantitative evaluation of the bioclastic components, obtained by physical separation and by weighing the shells and shell fragments, shows that this fraction varies strongly: from a minimum of $1 \%$ to a maximum of over $50 \%$ by weight (this equals some $70 \%$ by volume). The distinction between bioclastic and lithoclastic particles indicates that the beach sands should be classified as carbonate extraclastic hybrid sands, except for one sample which can be classified as a hybrid sand or a bioclastic hybrid sand, depending on whether the weight or volume of the various components is considered.

The ecological/biological survey carried out in the various marine sub-environments made clear which are the source areas of the various kinds of bioclasts that are present in the sands. Most of the bioclasts are shells and fragments of bivalves and gastropods. Forty taxa $(72.7 \%$ of the total) come from sandy and rocky submerged shallow environments, in particular from the biocenosis of infralittoral algae and from the facies with vermetids. A smaller number of taxa ( $16.4 \%$ of the total) comes from deeper zones, especially from seagrasses and from coralligenous complexes.

Finally, a group of mollusc shells belongs to parasites that live in various sub-environments; only one taxon is typical of brackish environments. It seems evident that there are multiple sources of bioclasts and that these sources are characterised by different ecological parameters (salinity, depth, light, type of substratum, presence of vegetation, presence of bioconstructors). Nevertheless, our study shows that the most important source areas are located within the shoreface and offshore transition environments (only 16.4\% comes from deeper environments).

\section{Conclusive remarks}

We have analysed sands of a beach located along the Adriatic coast of the Apulian region at Rosa Marina (north of Brindisi) with the objective to characterise in detail the lithoclast and bioclastic components, so that the source of the beach sands could be traced. The beach was analysed for the purpose from both a physical point of view (geomorphology and sedimentology) and an ecological/biological point of view. This approach was considered the most appropriate because beaches are the result of a combination of several physical processes (erosion, transport and sedimentation) and biological agents that interact at various scales and at different times.

A first important conclusion is related with the comparative analyses carried out concerning the composition of the present-day beach sands and regarding the sedimentary units cropping out in the coastal area. We come to the conclusion that the lithoclast component of the present-day beach sands is controlled by storm-wave erosion of the rocky substratum, without a necessary contribution from longshore sediment transport. Furthermore, the sedimentary units of the recent coastal dunes have a composition that is highly similar to the present-day beach sands; this conclusion seems only logical considering the unchanged or similar palaeogeographical situation during the late Pleistocene-Holocene.

Another important conclusion regarding the coastal erosion can be drawn from the bioclastic content: also in beaches with an insignificant bioclastic content (in one sample it was close to only $1 \%$ ), such as in the case of the study area, a considerable coastal retreat can occur in only a few years by the loss or by a drastic decrease of the bioclastic input. This conclusion indicates how important a detailed study is of the bioclastic components of the sands by identification of the taxa that supply sedimentary material to the beach. The natural bioclastic supply to the beach depends on the health state of these environments and on the possibility to host, to feed, to provide shelter and to be a breeding site for taxa that, one day, will become bioclasts.

The results of this study also indicate how effective and less expensive procedures can be developed to prevent or minimize coastal erosion. In this context we think it of potentially great social importance to emphasise the enormous potential of geological/biological multidisciplinary approaches in the study of beaches: most important are (1) the characterisation of the physical/biological/ecological environment, (2) the analysis and monitoring of 
the phenomena involved in coastal retreat, (3) the investigation and characterisation of materials that can be useful for beach nourishment, and (4) the analysis of ecological impacts in the widest sense at every stage of beach nourishment.

\section{References}

Anfuso, G., Pranzini, E. \& Vitale, G., 2011. An integrated approach to coastal erosion problems in Northern Tuscany (Italy). Littoral morphological evolution and cell distribution. Geomorphology 129, 204-214.

Annese, R., De Marco, R., Gianfreda, F., Mastronuzzi, G. \& Sanso, P., 2003. Caratteri morfo-sedimentologici della Baia di Torre Canne (Brindisi, Puglia) [Morpho-sedimentary characteristics of the Torre Canne Bay (Brindisi, Puglia)]. Studi Costieri 7, 3-19.

Anthony, E.J., 2009. Shore processes and their paleoenvironmental applications. Developments in Marine Geology 4, 519 pp.

APAT-ICRAM, 2007. Manuale di movimentazione dei sedimenti marini [Handbook of marine sediment transport]. 77 pp. (http://www.isprambiente.gov.it/contentfiles/00006700/6770-manuale-apaticram-2007.pdf/ view).

Barcelona Convention, 1997. Convention for the Protection of the Marine Environment and the Coastal Region of the Mediterranean, 22 pp. (http://195.97.36.231/dbases/ webdocs/BCP/bc95_Eng_p.pdf).

Bird, E., 2008. Coastal geomorphology - an introduction. $2^{\text {nd }}$ ed. Wiley and Sons, $411 \mathrm{pp}$.

Blott, S.J. \& Pye, K., 2001. GRADISTAT: a grain size distribution and statistics package for the analysis of unconsolidated sediments. Earth Surface Processes and Landforms 26, 1237-1248.

Charlier, R.H. \& De Meyer, C.P., 1998. Coastal erosion. Lecture Notes in Earth Sciences, Springer, 70, 343 pp.

Chiocci, F.L. \& La Monica, G.B., 1999. Individuazione e caratterizzazione dei depositi sabbiosi presenti sulla piattaforma continentale della Regione Lazio e valutazione di un loro utilizzo ai fini del ripascimento dei litorali in erosione - Rapporto finale della I fase [Identification and characterisation of sand deposits on the continental shelf of the Lazio region and assessment of their use in the nourishment of retreating coastlines - First phase final report]. Università degli Studi di Roma 'La Sapienza', Rome, 110 pp.

Choquette, P.W. \& Pray, L.C., 1970. Geologic nomenclature and classification of porosity in sedimentary carbonates. American Association of Petroleum Geologists Bulletin 54, 207-250.

Ciaranfi, N., Pieri, P. \& Ricchetti, G., 1988. Note alla carta geologica delle Murge e del Salento (Puglia centromeridionale) [Notes to the geological map of Murgia and Salento (south-central Puglia)]. Memorie della Società Geologica Italiana 41, 449-460.

Colosio, F., Abbiati, M. \& Arnoldi, L., 2007. Effects of beach nourishment on sediments and benthic assemblages. Marine Pollution Bulletin 54, 1197-1206.
Dal Cin, R., 1969. Distinzione tra spiagge in erosione ed in avanzamento mediante metodo granulometrico [Distinction between retreating and advancing beaches through particle size method]. Rivista Italiana di Geotecnica 4, 227-233.

Finkl, W., 1981. Beach nourishment, a practical method of erosion control. Geo-Marine Letters 1, 155-161.

Flügel, E., 2004. Microfacies of carbonate rocks. Springer, 976 pp.

Fredsøe, J. \& Deisgaard, R. (Eds), 1994. Mechanics of coastal sediment transport. Advanced Series on Ocean Engineering 3, $369 \mathrm{pp}$.

Gallicchio, S., Moretti, M., Spalluto, L. \& Angelini, S., 2014. Geology of the middle and upper Pleistocene marine and continental terraces of the northern Tavoliere di Puglia plain (Apulia, southern Italy). Journal of Maps 10, 569-575.

Gioia, D., Gallicchio, S., Moretti, M. \& Schiattarella, M., 2014. Landscape response to tectonic and climatic forcing in the foredeep of the southern Apennines, Italy: insights from Quaternary stratigraphy, quantitative geomorphic analysis, and denudation rate proxies. Earth Surface Processes and Landforms 39, 814-835.

Greenwood, B. \& Davis Jr, A.R. (Eds), 1984. Hydrodynamics and sedimentation in wave-dominated coastal environments. Developments in Sedimentology 39, 473 pp.

Ingle Jr, J.C. (Ed.), 1966. The movement of beach sand. Developments in Sedimentology 5, 221 pp.

Jackson, D.R. \& Richardson, M.D., 2007. High-frequency seafloor acoustics. Springer, $616 \mathrm{pp}$.

Kay, R. \& Alder, J., 2002. Coastal planning and management. Taylor \& Francis, 387 pp.

Mastronuzzi, G. \& Sanso, P., 2002. Holocene coastal dune development and environmental changes in Apulia (Southern Italy). Sedimentary Geology 150, 139-152.

Mastronuzzi, G., Palmentola, G. \& Sanso, P., 2001. Evoluzione morfologica della fascia costiera di Torre Canne (Puglia adriatica) [Morphological evolution of the Torre Canne coastline (Adriatic Apulia)]. Studi Costieri 4, 19-31.

Mastronuzzi, G., Palmentola, G. \& Sansò, P., 2002. Lineamenti e dinamica della costa pugliese [Features and dynamics of the Apulian coast]. Studi Costieri 5, 9-22.

Moretti, M., Owen, G. \& Tropeano, M. 2011. Soft-sediment deformation induced by sinkhole activity in shallow marine environments: A fossil example in the Apulian Foreland (Southern Italy). Sedimentary Geology 235, 331-342.

Mount, J., 1985. Mixed siliciclastic and carbonate sediments: a proposed first-order textural and compositional classification. Sedimentology 32, 435-442.

NRC (National Research Council), 1989. Measuring and understanding coastal processes. National Academies Press (http://www.nap.edu/catalog/1445.html).

NRC (National Research Council), 1994a. Environmental science in the coastal zone - issues for further research (http://www.nap.edu/catalog/2249.html).

NRC (National Research Council), 1994b. Priorities for coastal ecosystem science (http://www.nap.edu/catalog/ 4932.html). 
Nicoletti, L., Paganelli, D. \& Gabellini, M., 2006. Aspetti ambientali del dragaggio di sabbie relitte a fini di ripascimento: proposta di un protocollo di monitoraggio [Environmental aspects of relict sand dredging for beach nourishment: proposal for a monitoring protocol]. Quaderno ICRAM 5, 150 pp.

Nordstrom, K.F., 2005. Beach nourishment and coastal habitats: research needs to improve compatibility. Restoration Ecology 13, 215-222.

Peres, J.M. \& Picard, J., 1964. Nouveau manuel de bionomie benthique de la Mer Méditerranée [A new manual for the bentic bionomics in the Mediterranean Sea]. Recueil des Travaux de la Station Marine d'Endoume 47, 1-37.

Pettijohn, F.J., 1975. Sedimentary rocks. $3^{\text {rd }}$ ed. Harper and Row, $628 \mathrm{pp}$.

Puglia Region, 2006. Miglioramento delle conoscenze di base, adeguamento e ampliamento del sistema di monitoraggio del suolo, dei corpi idrici superficiali, sotterranei e costieri [Improvement of the basic knowledge, adaptation and expansion of the monitoring system of soil, surface, underground and coastal water bodies]. POR 2000-2006. Misura 1.3. Area d'azione 2 e 4, Pilone, 3 pp.

Puglia Region, 2012. Attività finalizzate alla redazione del Piano Regionale delle Coste (P.R.C.) della Regione Puglia [Activities for the preparation of the Regional Plan of Coste (PRC) of the Puglia Region]. POR 2012, All. n. 7.1.2, L'erosione costiera in Europa, in Italia e in Puglia [Coastal erosion in Europe, Italy and Puglia]. Bollettino Ufficiale Regione Puglia 1, 6123-6142 (http:// $\mathrm{w} w \mathrm{w}$.regione.puglia.it $/$ index.php? page $=\mathrm{docu}-$ menti\&opz=getdoc\&id=229).

Relini, G. \& Giaccone, G., 2009. Gli habitat prioritari del protocollo SPA/BIO (Convenzione di Barcellona) presenti in Italia. Schede descrittive per l'identificazi- one [The priority habitats of the Protocol SPA / BIO (Barcelona Convention) in Italy. Illustrative sheets for identification]. Biologia Marina Mediterranea 16, 1-372.

Schlager, W., 2005. Carbonate sedimentology and sequence stratigraphy. Concepts in Sedimentology and Paleontology, SEPM 8, 200 pp.

Schwartz, M.L., 2005. Encyclopedia of coastal science. Springer, $1211 \mathrm{pp}$.

Tropeano, M. \& Spalluto, L., 2006. Present-day temperate-type carbonate sedimentation on Apulia shelves (southern Italy). GeoActa 5, 129-142.

Tropeano, M., Sabato, L. \& Pieri, P., 2002. Filling and cannibalization of a foredeep: the Bradanic Trough (Southern Italy). [In:] S.J. Jones \& L.E. Frostick (Eds): Sediment flux to basins: causes, controls and consequences. Geological Society of London, Special Publications $191,55-79$

Uda, T., 2010. Japan's beach erosion - reality and future measures. Advanced Series on Ocean Engineering 31, 418 pp.

van der Salm, J. \& Unal, O., 2003. Towards a common Mediterranean framework for beach nourishment projects. Journal of Coastal Conservation 9, 35-42.

van Rijn, L.C., 2011. Coastal erosion and control. Ocean and Coastal Management 54, 867-887.

Zuffa, G.G., 1980. Hybrid arenites: their composition and classification. Journal of Sedimentary Petrology 50, 21-29.

Zuffa, G., 1985. Optical analysis of arenites: influence of methodology on compositional results. [In:] G.G. Zuffa (Ed.): Provenance of arenites. Reidel, Dordrecht, 165-189.

Manuscript received: 21 September 2015 Revision accepted: 29 February 2016 